\title{
A CRITICAL EXAMINATION OF THE CJEU JUDGEMENT IN RENCKHOFF CASE: NEW FRONTIERS OF INTERNET CENSORSHIP
}

\author{
Bartłomiej ORĘZIAK ${ }^{1}$
}

\begin{tabular}{l|l} 
This paper analyzes the judgment of the Court of Justice of the European Union (CJEU) in \\
the Renckhoff case (C-161/17). First, the introductory remarks outline the background of \\
the core issue, mainly by presenting the current line of the CJEU's case law in cases based \\
on the same legal norm. They also highlight the distinctive character of the judgment in \\
the Renckhoff case. Next, some relevant facts determining the law-based approach are \\
presented, along with the key case-law theses put forward by the CJEU to justify its deci- \\
sion. These considerations underpin the deliberations on censorship of Internet content, \\
based on copyright law. The observations here refer the findings to the principles of \\
freedom of expression as featured in both national and international law. The paper \\
ends with a summary of the author's observations on the core issue.
\end{tabular}

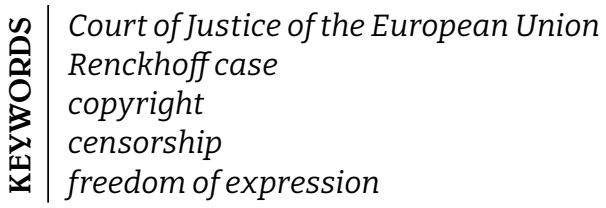

\section{Introduction}

The starting point for the analysis of the issue at hand is Directive 2001/29/EC of the European Parliament and the Council of May 22, 2001 on harmonizing certain aspects of copyright and related rights in the information society ${ }^{2}$ (Directive 2001/29/EC). This act of secondary EU law was adopted based on Articles 53, 62, and 114 of the Treaty on the Functioning of the European Union ${ }^{3}$ (TFEU). This means that in this respect, the EU

1 | Researcher, Faculty of Law and Administration, Cardinal Stefan Wyszyński University in Warsaw, b.oreziak@uksw.edu.pl.

2 | Directive 2001/29/EC of the European Parliament and of the Council of May 22, 2001 on the harmonisation of certain aspects of copyright and related rights in the information society (OJ L 167, 22.6.2001, pp. 10-19).

3 | Consolidated version of the Treaty on the Functioning of the European Union (OJ C 326, October 26, 2012, pp. 47-390). 
legislator decided to apply a method based on the harmonization of national laws of the EU member states, and not on their unification, where the proper legal form would be regulation. The application of Directive 2001/29/EC has proved in practice that its wording often requires clarification by an autonomous CJEU interpretation. ${ }^{4} \mathrm{Art} .3(1)$ is one of the provisions of Directive 2001/29/EC, posing interpretation difficulties with regard to the problem that is the main point of reference here. It provides that,

"Member States shall provide authors with the exclusive right to authorise or prohibit any communication to the public of their works, by wire or wireless means, including the making available to the public of their works in such a way that members of the public may access them from a place and at a time individually chosen by them."

Of interest to us is a fragment of this wording that still poses an interpretative difficulty. It concerns the concept of 'communication to the public' of legally protected content by making it available on the Internet, which can be referred to at least two basic groups of facts in specific court cases. The first of these comprises cases where the CJEU made an autonomous interpretation of the concept of 'communication to the public' used in Art. 3(1) of Directive 2001/29/EC in a situation where some content was made available on the Internet for the first time without the consent of the copyright holder. This means that legally protected content entered the internet illegally, without the consent of the copyright holder or even against their will. Situations in this group of facts relate most often to songs or videos for free use posted on various websites, most often in violation of the copyright of their respective holders. It seems obvious that the initial communication of protected content on the Internet should be penalized. However, it is interesting to analyze how to approach this issue in the case of Internet users, often private individuals, who further make such content on the Internet available. They may not be aware that they provide links to materials that have ended up on the internet without the consent of the copyright holder. The case-law of the CJEU is relevant here, particularly the rulings that furnish the basic arguments to determine the principles and factors that determine the lawfulness of posting hyperlinks to illegal web content. These are primarily the following CJEU judgements: on February 13, 2014, in case C-466/12 Nils Svensson, Sten Sjögren, Madelaine Sahlman, Pia Gadd v Retriever Sverige $A^{5}$; on September 8, 2016, in case C-160/15 GS Media v Sanoma Media Netherlands BV, Playboy Enterprises International Inc., Britt Geertruida Dekker6; of the CJEU of April 26, 2017, in case C-527/15 Stichting

4 | For example: Judgement of the CJEU of July 29, 2019 in case C-469/17 Funke Medien NRW GmbH v Bundesrepublik Deutschland (ECLI:EU:C:2019:623); Judgement of the CJEU of September 12, 2019 in case C-683/17 Cofemel - Sociedade de Vestuário SA v G-Star Raw CV (ECLI:EU:C:2019:721); Judgement of the CJEU of November 14, 2019 in case C-484/18 Société de perception et de distribution des droits des artistes-interprètes de la musique et de la danse (Spedidam), PG, GF v Institut national de l'audiovisuel (INA) (ECLI:EU:C:2019:970); Judgement of the CJEU of June 11, 2020 in case C-833/18 SI, Brompton Bicycle Ltd v Chedech/Get2Get (ECLI:EU:C:2020:461).

5 | Judgement of the CJEU of February 13, 2014 in case C-466/12 Nils Svensson, Sten Sjögren, Madelaine Sahlman, Pia Gadd v Retriever Sverige AB (ECLI:EU:C:2014:76); See Axhamn, 2015, pp. 847-866; K. Erdem and D. Erdem, 2019, pp. 1618-1623; Minero, 2014, pp. 322-327.

6 | Judgement of the CJEU of September 8, 2016 in case C-160/15 GS Media v Sanoma Media Netherlands BV, Playboy Enterprises International Inc., Britt Geertruida Dekker (ECLI:EU:C:2016:644); See Radosavljev, 2017, p. 5; Rosati, 2017, pp. 1221-1230; Long, 2018, pp. 430-433. 
Brein v Jack Frederik Wullems; ; and on June 14, 2017, in case C-610/15 Stichting Brein v Ziggo BV, XS4ALL Internet BV. ${ }^{8}$ These judgments cover a situation where a hyperlink posted links to content unlawfully published content on the Internet from a copyright point of view. It is there that one can find out how this specific legal argument originated. However, the nature of the judgment of the CJEU on August 7, 2018, in the case C-161/17 Land Nordrhein-Westfalen $v$ Dirk Renckhoff, ${ }^{9}$ as indicated in the title of this paper, is different. This judgment is the voice of the CJEU with regard to the second group of rulings relevant to the matters under consideration. The Renckhoff case concerns situations in which a hyperlink links to content communicated on the Internet for the first time with the consent of the copyright holder. It seems that limiting and setting out the conditions for the lawfulness of a subsequent communication (posting a hyperlink) would raise much more controversy and be more difficult to justify in terms of freedom of expression and allegations of unfounded and (therefore, going beyond what is necessary) censorship. For this reason, it is precisely this ruling that will be analyzed further in terms of consistency with the freedom of expression standard, which in practice is intended to protect against unlawful censorship. It is also not irrelevant whether the restrictions are based on the premise of the commercial purpose of communication to the public, where a distinction should be made between professional entities and ordinary Internet users. An additional reason for this decision to examine the issue at hand is the recent case law of the CJEU, which confirms that the lawfulness of posting hyperlinks to copyright-protected content available on the Internet is still valid. ${ }^{10}$

\section{The facts of the Renckhoff case}

The Renckhoff case began in Germany. On March 25, 2009, a presentation prepared by one of the students was published on a website administered by a secondary school

7 | Judgement of the CJEU of April 26, 2017 in case C-527/15 Stichting Brein v Jack Frederik Wullems (ECLI:EU:C:2017:300); see Ginsburg, 2017, pp. 4-5; Colangelo and Maggiolino, 2018, pp. 142-159.

8 Judgement of the CJEU of June 14, 2017 in case C-610/15 Stichting Brein v Ziggo BV, XS4ALL internet BV (ECLI:EU:C:2017:456); Nordemann, 2018, pp. 744-756; Koo, 2018, pp. 542-551; Visser, 2018a, pp. 1025-1026.

9| Judgement of the CJEU of August 7, 2018 in case C-161/17 Land Nordrhein-Westfalen v Dirk Renckhoff (ECLI:EU:C:2018:634) - the case name hereinafter abbreviated as 'Renckhoff'; Wang, 2018, pp. 61-65; Visser, 2018b, p. 183-190; Fernández-Díez, 2018, p. 2.

10 Judgement of the CJEU of June 22, 2021 in joined cases C-682/18 and C-683/18 in Frank Peterson v Google LLC, YouTube Inc., YouTube LLC, Google Germany GmbH (C-682/18) and Elsevier Inc. v Cyando AG (C-683/18) (ECLI:EU:C:2021:503); Judgement of the CJEU of December 19, 2019 in case C-263/18 Nederlands Uitgeversverbond, Groep Algemene Uitgevers v Tom Kabinet internet BV, Tom Kabinet Holding BV, Tom Kabinet Uitgeverij BV (ECLI:EU:C:2019:1111); Judgement of the CJEU of April 2, 2020 in case C-753/18 Föreningen Svenska Tonsättares Internationella Musikbyrå u.p.a. (Stim), Svenska artisters och musikers intresseorganisation ek. för. (SAMI) v Fleetmanager Sweden AB, Nordisk Biluthyrning AB (ECLI:EU:C:2020:268); Judgement of the CJEU of October 28, 2020 in case C-637/19 BY v CX (ECLI:EU:C:2020:863); Judgement of the CJEU of 9 March 2021 in case C-392/19 VG Bild-Kunst v Stiftung Preußischer Kulturbesitz (ECLI:EU:C:2021:181); Judgement of the CJEU of June 17, 2021 in case C-597/19 Mircom International Content Management \& Consulting (M.I.C.M.) Limited v Telenet BVBA (ECLI:EU:C:2021:492). 
in Waltrop. ${ }^{11}$ The presentation contained a photograph taken by Dirk Renckhoff that had been downloaded from another travel website with no restriction preventing it from being downloaded (Recital 7). Under the photograph, the student referenced the website from which she downloaded it (Recital 7). Dirk Renckhoff, seeing that as the copyright holder of his photograph, brought an action before the national court in Hamburg, suing the city of Waltrop as responsible for running the secondary school in that city and the land of North Rhine-Westphalia, which supervised that school (Recitals 6 and 7). Thus, the main proceedings of Germany began. Dirk Renckhoff indicated in his statement of claim that although he indeed had given his consent to have his photograph posted on the internet on the travel portal, his consent, as to the subject and object, did not extend to the entire internet, but only that one portal, and the fact that his photo was posted without a restriction preventing it from being downloaded did not matter (Recitals 7 and 8). Thus, Dirk Renckhoff argued that his copyrights in the context of the disputed photograph had been infringed and demanded that the Land of North Rhine-Westphalia be prohibited 'on pain of a financial penalty, from reproducing/having reproduced and/or making available/having made available to the public the photo and, in the alternative, from allowing school students to reproduce the photo for purposes of posting it on the Internet. He also claimed payment of damages from the Land of North Rhine-Westphalia of EUR 400' (Recital 8). As the claim was partially upheld at first instance, all parties to the proceedings appealed against the judgment of the Higher Regional Court in Hamburg (Recitals 9 and 10). To the extent relevant to the issue under consideration, the court decided that the disputed photograph had been protected under the copyright law and that its placement on the website had violated the right to communicate it to the public (Art. 3(1) of Directive 2001/29/EC), which in that case remained with Dirk Renckhoff (Recital 10). Interestingly, the Higher Regional Court in Hamburg pointed out that the fact that the photograph in question was available on the Internet without any restrictions was irrelevant, 'since the reproduction of the photograph on the server and the making available to the public on the school website which followed led to a 'disconnection' with the initial publication on the online travel portal' (Recital 10). This decision was appealed on the point of law to the Federal Court of Justice, which rightly noticed that the assessment of the facts, in essence, depended on the correct interpretation of Art. 3(1) of Directive 2001/29/EC (Recital 11), about which it had doubts as to one of the requirements laid down in the case law for the lawfulness of hyperlinking to copyrighted content available on the Internet (Recital 11). Under the circumstances that court stayed the main proceedings and, pursuant to Art. 267 TFEU, decided under its ruling of February 23, 2017, to refer a question to the CJEU for a preliminary ruling, which read as follows:

\footnotetext{
"Does the inclusion of a work-which is freely accessible to all internet users on a third-party website with the consent of the copyright holder-on a person's own publicly accessible website constitute a making available of that work to the public within the meaning of Art. 3(1) of Directive 2001/29 if the work is first copied onto a server and is uploaded from there to that person's own website?" (Recital 12).
}

Incidentally, one should note that the Federal Court of Justice naturally associated the facts presented before it with the court cases examined by the CJEU, which concerned the 
interpretation of Art. 3(1) of Directive 2001/29/EC in the context of hyperlinking content available on the Internet without the consent of the copyright holder, so that their initial communication to the public was unlawful. ${ }^{12}$ This association was natural and seemed to be correct at the time; however, as it will turn out later, according to the CJEU, there is a significant difference between these sets of facts. In simple terms, the difference is that, in the Renckhoff case, there is a subsequent communication to the public of protected content that was originally made available on the internet with the consent of the copyright holder.

\section{The position of the Court of Justice of the European Union}

It would go far beyond the scope of this paper to present the entire argument of the CJEU at this point. Therefore, it is necessary to limit the analysis to the relevant recitals selected by the author. First, the CJEU (typically) set out what the Federal Court of Justice was attempting to achieve. The CJEU assumed that the core of the question asked is

\footnotetext{
"whether the concept of 'communication to the public', within the meaning of Art. 3(1) of Directive 2001/29, must be interpreted as meaning that it covers the posting on one website of a photograph which has been previously published without restriction and with the consent of the copyright holder on another website." ${ }^{13}$
}

The CJEU, having pointed out the conditions that the disputed photo should meet, ${ }^{14}$ so that it could be protected by copyright, recalled that one of the objectives of Art. 3 (1) of Directive 2001/29/EC was to provide authors with the exclusive right to authorize or prohibit communication to the public of their works. ${ }^{15}$ Other judgments of the CJEU show that the use of protected content by other persons without the prior consent of the copyright holder should be considered a copyright infringement. ${ }^{16}$ In other words, in the opinion of the CJEU, justified by Recitals 4, 9, and 10 of Directive 2001/29/EC, the objective of the legal norm in question was to guarantee a sufficiently high level of copyright protection, which is directly related to the respect for the choices of the copyright holder in making the protected content available to the public. ${ }^{17}$ On that basis, the CJEU concluded that the concept of 'communication to the public' must be interpreted broadly, as confirmed by Recital 23 of Directive 2001/29/EC. ${ }^{18}$ The CJEU recalled that the concept of 'communication to the public', as used in Art. 3(1) of Directive 2001/29/EC included two cumulative criteria. First,

12 | In particular: Judgement of the CJEU of 8 September 2016 in case C-160/15...; Judgement of the CJEU of 26 April 2017 in case C-527/15...; Judgement of the CJEU of 14 June 2017 in case C-610/15...

13 | Judgement of the CJEU (Renckhoff), Recital 13.

14 I Judgement of the CJEU (Renckhoff), Recital 14; Judgement of the CJEU of December 1, 2011, Painer, C-145/10.

15 | Judgement of the CJEU (Renckhoff), Recital 15.

16 | Judgement of the CJEU (Renckhoff), Recital 15; Judgement of the CJEU of November 16, 2016, Soulier and Doke, C-301/15.

17 | Judgement of the CJEU (Renckhoff), Recital 18; Judgement of the CJEU of June 14, 2017, Stichting Brein, C-610/15.

18 | Judgement of the CJEU (Renckhoff), Recital 18. 
there must be an 'act of communication' of protected content and the communication of that content to a 'public'.19 According to the CJEU, an act of communication exists where content is made available to a public in such a way that the persons forming that public may access it, irrespective of whether or not they avail themselves of that opportunity'. ${ }^{20}$ In the Renckhoff case, the CJEU had no doubt that it was clear from the facts that the first criterion had been met, and proceeded to analyze the second criterion. ${ }^{21}$ The criterion that the protected work must be communicated to a 'public', in the opinion of the CJEU, was met if the communication was made to an indeterminate and fairly large number of potential recipients and was made using specific technical means, different from those used for initial 'communication to the public'. ${ }^{22}$ On the other hand, where the technical means were identical, as in the Renckhoff case, ${ }^{23}$ it was necessary to determine whether the subsequent communication was to a 'new public', that is, to a public that was not already taken into account by the copyright holders when they authorized the initial communication to the public of their work (Recital 24). The CJEU, based on the facts of the Renckhoff case, had no doubt that the second criterion of 'communication to Waltrip the public' was met as regards the concept of a 'new public' (Recitals 23 and 35). The main argument presented in support of this interpretation is the statement that

\begin{abstract}
"Article 3 (3) of Directive 2001/29 specifically provides that the right of communication to the public referred to in Article 3 (1) of that directive is not exhausted by any act of communication to the public or making available to the public within the meaning of that provision" (Recitals 23 and 32 ).
\end{abstract}

In addition, the CJEU also emphasized that the fact that the copyright holder did not limit the possibility for Internet users to use the photograph was irrelevant, as the enjoyment and the exercise of the right provided for in Art. 3(1) of Directive 2001/29/EC may not be subject to any formality (Recital 36). ${ }^{24}$ Interestingly, to conclude its case-law argumentation, the CJEU emphasized that to recognize the activity being the essence of the Renckhoff case as not meeting the criteria of 'communication to the public' would violate the balance referred to in Recitals 3 and 31 of Directive 2001/29/ EC,

"which must be maintained in the digital environment between, on the one hand, the interest of the holders of copyright and related rights in the protection of their intellectual property, guaranteed by Article 17 (2) of the Charter of Fundamental Rights of the European Union and,

19 | Judgement of the CJEU (Renckhoff), Recital 19; Judgement of the CJEU of March 16, 2017, AKM, C-138/16; Judgement of the CJEU of June 14, 2017, Stichting Brein, C-610/15.

20 I Judgement of the CJEU (Renckhoff), Recital 20; Judgement of the CJEU of February 13, 2014, Svensson and Others, C-466/12; Judgement of the CJEU of June 14, 2017, Stichting Brein, C-610/15.

21 I Judgement of the CJEU (Renckhoff), Recital 21.

22 | Ibid., Recitals 22 and 24; Judgement of the CJEU of 13 February 2014, Svensson and Others, C466/12; Judgement of the CJEU of June 14, 2017, Stichting Brein, C-610/15; Judgement of the CJEU of September 8, 2016, GS Media, C-160/15.

23 | The initial communication of the photograph on the internet with the consent of the copyright holder on the travel portal and its subsequent communication on the school website were made by exactly the same technical means, that is, the internet (Judgement of the CJEU [Renckhoff], Recital 25).

24 | Also Judgement of the CJEU of November 16, 2016, Soulier and Doke, C-301/15. 
on the other hand, the protection of the interests and fundamental rights of users of protected subject matter, in particular their freedom of expression and information guaranteed by Article 11 of the Charter of Fundamental Rights, as well as the public interest" (Recital 41).

This is a very interesting conclusion by the CJEU, which should be addressed later in our analysis. The CJEU, given all the arguments and the facts of the case, decided finally that 'having regard to all of the foregoing considerations, the answer to the question referred is that the concept of 'communication to the public', within the meaning of Art. 3 (1) of Directive 2001/29, must be interpreted as meaning that it covers the posting on one website of a photograph previously posted, without any restriction preventing it from being downloaded and with the consent of the copyright holder.'25

\section{Assessment of the position of the Court of Justice of the European Union}

The CJEU's approach to the Renckhoff case seems peculiar. Nothing prevented it from using the previously developed model for assessing the lawfulness of hyperlinking on the Internet, which was known from other judgments concerning subsequent communication; after all, those provided for a more extensive system of principles and criteria of liability for copyright infringement by subsequent communication of protected content originally made available on the internet without the consent of the copyright holder. ${ }^{26}$ It was in that case law that the criteria of a for-profit nature and a subjective assessment of knowledge of copyright infringement were used. The for-profit nature criterion relied on a distinction between Internet users who make subsequent communication professionals and those who are non-professionals, using the Internet, and not seeking financial gain. This distinction is extremely important, as it entails two fundamental assumptions regarding the assessment of the subjective knowledge of infringement. ${ }^{27}$ The first is that an Internet user making secondary communication of copyrighted content for a profit knows or can reasonably know that such content was initially published without the consent of the copyright holder. In contrast, under the second one, an Internet user making secondary communication of copyrighted content other than for a profit does not know or cannot reasonably know that such content was initially published without the consent of the copyright holder. Both of these presumptions are legally rebuttable, for example (for the latter) by indicating that the user who communicates a protected work has been instructed by the copyright holder about the infringement or the hyperlink that they communicate aims to circumvent the security of the website, which consists of deliberately restricting access to the group of subscribers on that website. ${ }^{28}$ In the Renckhoff case, the CJEU could use that model of principles and criteria for determining

25 | Judgement of the CJEU (Renckhoff), Recital 47.

26 I Judgement of the CJEU of September 8, 2016 in case C-160/15...; Judgement of the CJEU of 26 April 2017 in case C-527/15...; Judgement of the CJEU of June 14, 2017 in case C-610/15...

27 | Judgement of the CJEU of September 8, 2016 in case C-160/15... Recital 55.

28 | Ibid., Recital 50. 
the lawfulness of web hyperlinks. It was only sufficient to adjust the above presumptions to the facts of the case, where the initial communication was made with the consent of the copyright holder limited as to the subjects permitted to communicate. After such adjustment, de lege ferenda the presumptions in question should be worded so that an Internet user - making subsequent communication of copyrighted content for a profit initially communicated on the Internet with the consent of the copyright holder limited as to subjects permitted to communicate - knows or can reasonably know that such content was originally published with the consent of the copyright holder so limited. The latter presumption would consistently indicate that an Internet user - making a not-for-profit subsequent communication of copyrighted content initially communicated on the Internet with the consent of the copyright holder limited as to the subjects permitted to communicate - does not know or cannot reasonably know that such content was originally published with the consent of the copyright holder so limited. Both of these assumptions are also rebuttable. The CJEU could have done this to demonstrate the logical consistency of its case law. However, as noted above, the CJEU chose a different path for autonomous interpretation. However, it is difficult to determine the reasons for this decision. The Renckhoff case was not burdened with pejorative elements as in the judgment of the CJEU of 14 June 2017 in case C-610/15 Stichting Brein v Ziggo BV, XS4ALL Internet BV. One can even say that the facts favored the decision that the criteria 'communication to the public' under Art. 3(1) of Directive 2001/29/EC had not been met. After all, the case is about a student and her presentation, so not only the freedom of expression, which should be respected but also the right to education. Admittedly, the CJEU stated that its interpretation reflected the balance

"which must be maintained in the digital environment between, on the one hand, the interest of the holders of copyright and related rights in the protection of their intellectual property, guaranteed by Article 17 (2) of the Charter of Fundamental Rights of the European Union and, on the other hand, the protection of the interests and fundamental rights of users of protected subject matter, in particular their freedom of expression and information guaranteed by Article 11 of the Charter of Fundamental Rights, as well as the public interest." 29

Nevertheless, the ruling lacks proof of the truthfulness of this statement, and a mere statement is not sufficient. There is no in-depth analysis of the essence of the freedom of expression or the right to education, a reference to the relevant case law, or an analytical summary that would confirm that the balance upheld by the CJEU is real. As these elements are missing in the text of the judgment in the Renckhoff case, it seems that the CJEU claims for intellectual property rights, including copyright on the Internet, to have the status of an absolute right. It seems that the CJEU's position is that the balance between the rights of the copyright holder and other legal norms is maintained only if the copyright is fully protected without any prejudice. This interpretative approach is defective and requires a negative assessment.

For this reason, one should be critical of the decision taken by the CJEU in the Renckhoff case. We can argue that the CJEU typically and indicated that the concept of 'communication to the public' was an autonomous concept and its understanding depends on the interpretation of EU law. We can say that the term has its own specific meaning in 
the EU, not necessarily the same as the meaning it may have in the national law of the EU member states or what is commonly assigned to it. While this is true, the autonomous interpretation of the CJEU, like any other, may contain significant errors, implying serious consequences for the exercise of other rights of individuals. If these errors do occur, and it seems that they do occur in the Renckhoff judgment, then it is justified and necessary to point them out, and propose solutions to eliminate the irregularities in question. We can further say that in the Renckhoff case, Advocate General Manuel Campos SánchezBordona ${ }^{30}$ was also of the opinion that the CJEU should have taken a different decision. In his opinion,

\footnotetext{
"the inclusion on a school's website of an educational work that includes a photographic image freely available to any internet user free of charge, in that the image already appeared on the internet portal of a travel magazine with no warnings regarding restrictions on use, when there is no profit motive and the source is cited, does not constitute a making available to the public within the meaning of Article 3(1) of Directive 2001/29/EC of the European Parliament and of the Council of May 22, 2001, on the harmonization of certain aspects of copyright and related rights in the information society." ${ }^{31}$
}

This solution is another good alternative to the conclusion given in the Renckhoff ruling. Interestingly, the Advocate General, in his opinion (precisely in Recital 21), included the disputed photograph for illustrative purposes. It seems that he did not expect, according to the later judgment of the CJEU in the Renckhoff case, that he could be held liable for copyright infringement under exactly the same line of argument. This clearly shows the deficits in the Renckhoff ruling. Another argument can be used to challenge the judgment in the Renckhoff case. In line with the established CJEU case law, ${ }^{32}$ if the student had made a subsequent communication of copyrighted content initially made available on the internet illegally, that is, without the consent of the copyright holder, the CJEU would have applied the principles and criteria devised in the GS Media case and related rulings. Based on these, it would have concluded that the student, when making a subsequent communication of protected content, did not do so for a profit, and therefore on the presumption that she did not know or could not reasonably have known that such content was initially published without the consent of the copyright holder. This would have meant, first, that there was no infringement of copyright. One must also conclude that in light of the Renckhoff ruling, Internet users must expect a harsher reaction when they hyperlink to content legally available on the Internet, and a more lenient reaction when they hyperlink to content illegally available on the Internet. Logic seems to dictate that this relationship should be reversed. Given the above, one should emphasize that the arguments presented may be considered sufficient to conclude that the decision made in the Renckhoff case was incorrect.

30 | Opinion of Advocate General Manuel Campos Sánchez Bordona delivered on April 25, 2018 in Case C-161/17 Land Nordrhein-Westfalen v Dirk Renckhoff (ECLI:EU:C:2018:279).

31 Ibid., Recital 129.

32 I Judgement of the CJEU of September 8, 2016 in case C-160/15...; Judgement of the CJEU of 26 April 2017 in case C-527/15...; Judgement of the CJEU of June 14, 2017 in case C-610/15... 


\section{Censorship of internet content and the Renckhoff case}

For this chapter, censorship will mean control and restriction of the activities of Internet users, including their publication of content, particularly on political, moral, or legal grounds. ${ }^{33}$ This is a key reservation, as censorship does not cease to be censorship just because it is based on generally applicable law. It then becomes lawful censorship, as opposed to unlawful censorship, which in contemporary states ruled by law should never take place, and any occurrence should be met with a sanction adequate to the seriousness of the violation. However, this does not change that both types of censorship remain, in essence, censorship. Additionally, it does not affect the need to analyze the compliance of the use of censorship with specific standards of the international system for the protection of human rights, in particular the freedom of expression. The fact that censorship is based on a generally applicable law does not mean that it is legitimate. In this context, another issue is the presumption of the consistency of legal acts with the Constitution, which can be rebutted. ${ }^{34}$ Legal acts laying down the options for the use of censorship, as regards copyright for this paper, should be reviewed ex ante in terms of consistency with the principle of freedom of expression and pluralism. This is an ideal situation. According to Recital 3 of Directive 2001/29/EC, "the proposed harmonization will help to implement the four freedoms of the internal market and relates to compliance with the fundamental principles of law and especially of property, including intellectual property, freedom of expression, and the public interest." Therefore, it seems that such a review of compliance was taken into account by the EU legislator. However, because the CJEU autonomously interpreted the concept of 'communication to the public' as used in Art. 3 (1) of Directive 2001/29/EC, which was not originally defined in Directive 2001/29/EC, it is now necessary to perform an ex-post assessment of compliance with the standard of the freedom of expression, taking into account the case-law arguments of the CJEU in the Renckhoff judgment. Moreover, an ex post review of legal acts in compliance with the standards for the protection of human rights in legal sciences is common and has positive effects. One of the most important effects of such reviews is the opportunity to detect irregularities in the normative system and propose balanced de lege ferenda postulates in order to eliminate these.

\section{The freedom of expression standard and the Renckhoff case}

It makes little sense to quote the entire freedom of the expression standard. Let it suffice to cite the key important legal bases in force in the EU, the Council of Europe, and

33 | This proposal was developed by the author in another scholarly work.

34 | For example, this presumption, along with rebuttal options, is operative in Poland. In this regard, see: Judgement of the Constitutional Court (CC) of 11 July 2012, case ref. K 8/10; Judgement of the CC of 5 May 2011, case ref. P 110/08; Judgement of the CC of 25 May 2016, case ref. Kp 2/15; Judgement of the CC of 18 March 2004, case ref. P21/02; Radziewicz, 2008, pp. 55-86. 
Poland. Pursuant to Art. 11 of the Charter of Fundamental Rights of the European Union ${ }^{35}$ (EU CFR),

“1. Everyone has the right to freedom of expression. This right shall include freedom to hold opinions and to receive and impart information and ideas without interference by public authority, regardless of the frontiers. 2. The freedom and pluralism of the media shall be respected."

Pursuant to Art. 10 of the Convention for the Protection of Human Rights and Fundamental Freedoms ${ }^{36}$ (ECHR),

"Everyone has the right to freedom of expression. This right shall include freedom to hold opinions and to receive and impart information and ideas without interference by public authority, regardless of the frontiers. This article shall not prevent States from requiring the licensing of broadcasting, television, or cinema enterprises."

Pursuant to Art. 54 of the Constitution of the Republic of Poland,

"1. The freedom to express opinions, acquire, and disseminate information shall be ensured to everyone. 2. Preventive censorship of the means of social communication and the licensing of the press shall be prohibited. Statutes may require the receipt of a permit for the operation of a radio or television station."

Not without significance are other provisions of the EU CFR, the ECHR or the CRP, which indirectly support the implementation of the freedom of expression, which is extremely broad. For example, these include provisions concerning the freedom of the press, freedom and protection of the secret of communication, freedom of conscience and religion, and freedom of artistic creation. The indication of the above legal bases is intended to show that the freedom of expression is guaranteed in international and EU law relevant to the issue discussed in this paper, as well as in Polish law, which in this case is an example of national law. The freedom in question covers all levels of individual activity; it is an expression of the dignity of a person's autonomy and creates opportunities for the full development of personality in the cultural and civilizational environment of the individual. ${ }^{37}$ It should be emphasized here that Art. 10 of the ECHR concerns the freedom of all expressions, which covers not only the expression of views through speech but also in written, printed, or artistic forms. ${ }^{38}$ Art. 11 of the EU CFR has essentially the same meaning and should be understood similarly, as the Preamble to the EU CFR itself

35 | Charter of Fundamental Rights of the European Union (OJ C 326, 26.10.2012, p. 391-407).

36 | Convention for the Protection of Human Rights and Fundamental Freedoms signed in Rome on 4 November 1950, subsequently amended by Protocols No. 3, 5 and 8 and supplemented by Protocol No. 2 (Journal of Laws of 1993, No. 61, item 284).

37 In the context of freedom of speech, see Judgement of the CC of 12 May 2008, case ref. SK 43/05; Judgement of the CC of December 14, 2011, case ref. SK 42/09.

38 | Judgement of the CC of February 20, 2007, case ref. P1/06. 
suggests. ${ }^{39}$ On the other hand, Art. 54 CRP provides for the freedom to express one's views and to source and disseminate information in verbal, written, and printed forms, including through any means of social communication. ${ }^{40}$ This freedom is not absolute and is subject to weighting and limitations, as appropriate. For this reason, Art. 10 of the ECHR, in its paragraph 2, provides for formalities, conditions, restrictions or penalties prescribed

"by law and are necessary in a democratic society, in the interests of national security, territorial integrity, or public safety, for the prevention of disorder or crime, for the protection of health or morals, for the protection of the reputation or rights of others, to prevent the disclosure of information received in confidence, or for maintaining the authority and impartiality of the judiciary."

In addition, for this reason, Art. $31 \mathrm{CRP}$ provides that

"Any limitation upon the exercise of constitutional freedoms and rights may be imposed only by statute, and only when necessary in a democratic state for the protection of its security or public order, or to protect the natural environment, health, or public morals, or the freedoms and rights of other persons. Such limitations do not violate the essence of freedom and rights."

The conclusion is clear: freedom of expression or its constituent elements may be subject to limitations, but only such that is legally justified. In the case of the Renckhoff judgment, it is difficult to demonstrate such a justification. Let it suffice to indicate what consequences this judgment has in the practice of the functioning of the Internet for the freedom of expression. As there is no criterion of for-profit nature was used in the Renckhoff ruling, it applies to all Internet users. Since this ruling was issued, each internet user should obtain information about copyrighted content that they make available through subsequent communication. More precisely, a user should find out whether, for example, a photograph they share has been made available to the internet with or without the copyright holder's consent. If such consent was given, then what its extent is as to the subjects permitted to communicate. Otherwise, they are putting themselves, like the student or her school in the Renckhoff case, at risk of being held liable for copyright infringement. In practice, this can lead to the paralysis of hyperlinking in any form. It seems, however, that both the proper functioning of the Internet and the realization of the above-mentioned legal norms concerning the protection of human rights on the Internet, in principle, require that posting or publishing hyperlinks be permitted. It is not entirely clear what

39|'This Charter reaffirms, with due regard for the powers and tasks of the Union and for the principle of subsidiarity, the rights as they result, in particular, from the constitutional traditions and international obligations common to the Member States, the European Convention for the Protection of Human Rights and Fundamental Freedoms, the Social Charters adopted by the Union and by the Council of Europe and the case law of the Court of Justice of the European Union and of the European Court of Human Rights. In this context the Charter will be interpreted by the courts of the Union and the Member States with due regard to the explanations prepared under the authority of the Praesidium of the Convention which drafted the Charter and updated under the responsibility of the Praesidium of the European Convention' (Charter of Fundamental Rights...).

40 I Judgement of the CC of February 20, 2007, case ref. P 1/06. 
the Internet would look like without hyperlinking. However, it is certain that in this digital environment, hyperlinks are tools that recognize the freedom of expression both in the EU CFR, the ECHR, and the CRP. To make a definitive conclusion, one can and should discuss restrictions on the posting of hyperlinks leading to content illegally available on the Internet. In this case, there is a fair amount of pejorative implications and, at the same time, a strong need to ensure the protection of the legitimate interests of the copyright holder, who has not consented to 'communication to the public' of their content on the Internet. However, in a situation where the copyright holder has consented to the communication of their content on the Internet, they should be aware of the consequences of their choice. One of the major consequences, following from the nature of the Internet, is that a copyrighted work is 'communicated to the public' across the web, without any restrictions on permitted territories, objects, or subjects of communication. Given the unique nature of the Internet, consent of a copyright holder with a limited extent as to the subjects permitted to communicate (e.g., only to users of a selected website) should be deemed highly contrived and one that should not have legal effects, in particular given the objects of the freedom of expression. De lege ferenda, a legal presumption should be introduced into the normative system, according to which, when a copyright holder agrees to 'communication to the public' of their work on the internet within the meaning of Art. 3(1) of Directive 2001/29/EC, they know or should reasonably know that due to the specific nature of the internet, such consent is unlimited in terms of time, territory, subjects or objects. This presumption should be legally rebuttable, for example, by an indication by the copyright holder that they have consented to 'communication to the public' within the meaning of Art. 3(1) of Directive 2001/29/EC on a specific website with security measures that deliberately restrict access to the group of subscribers of that website (restrictions preventing the download of copyrighted content). To summarize, given the above, the decision made by the CJEU in the Renckhoff case should also be critically assessed in terms of, as shown in the above analysis, unjustified restriction of the freedom of expression on the Internet.

\section{Summary}

The Renckhoff ruling introduces censorship on the Internet with normative justification on copyright grounds. This censorship applies to the posting of hyperlinks to content communicated on the internet lawfully, that is, with the consent of the copyright holder. In this ruling, the CJEU failed to use the model it had developed for the admissibility of hyperlinking to content made available on the internet illegally, that is, without the copyright holder's consent. In particular, it did not use the criterion of for-profit nature of 'communication to the public, which provided and, to the extent covering the issue discussed in this paper, could provide a real balance between the standard of the freedom of expression and the legitimate claims of the copyright holder. The argumentation and interpretation of Art. 3(1) of Directive 2001/29/EC adopted in the Renckhoff case appear to be incompatible with the specific nature and content communicated principles of the Internet. The inaccuracy or even defectiveness of this ruling is one thing; its consequences for realizing the freedom of expression on the Internet in practice are another. It may paralyze hyperlinking in any form on the Internet, and thus disrupt the proper 
functioning of the Internet and cause an unjustified limitation of the implementation of legal norms related to the freedom of expression in the digital environment. It should be clearly emphasized that the comprehensive analysis carried out in this paper concludes that the court decision in the Renckhoff case may be deemed to be a normatively ungrounded restriction of the freedom of expression on the Internet. Further, it is striking with its illogical disharmony in the degree of severity of the response to a subsequent 'communication to the public' within the meaning of Art. 3(1) of Directive 2001/29/EC, where Internet users must expect a harsher reaction when hyperlinking content legally available on the Internet, and a more lenient reaction when hyperlinking content is illegally available on the Internet. To conclude the scholarly analysis above, first, the judgment in the Renckhoff case should be assessed critically in accordance with the presented arguments and to the substantive extent of these arguments; second, it is proposed that all the de lege ferenda postulates proposed in this regard be introduced into law. The latter can be achieved either by amending Directive 2001/29/EC and using the national law to implement this Directive, or a ruling issued by the CJEU, which will depart from the construction adopted in the Renckhoff case. 


\section{Bibliography}

Axhamn, J. (2015) 'Hyperlinking: Case C-466/12 Svensson and Others and Its Impact on Swedish Copyright Law', Europarättslig tidskrift, 18(4), pp. 847-866.

Colangelo, G., Maggiolino, M. (2018) 'ISPs' copyright liability in the EU digital single market strategy', International Journal of Law and Information Technology, 26(2), pp. 142-159.

Erdem, K., Erdem, D. (2015) ‘Avrupa Birliği Adalet Divanı'nın C-466/12 Sayılı ‘Svensson Kararı”, Terazi Hukuk Dergisi, 2015/14, pp. 1618-1623.

Fernández-Díez, I. (2018) 'La puesta a disposición de obras y prestaciones protegidas por quien no tiene la autorización de los titulares de derechos de propiedad intelectual cuando previamente se ha hecho accesible dicha obra en Internet con licencia del autor', La Ley Unión Europea, 2018/64, p. 2.

Ginsburg, J. (2017) 'The Court of Justice of the European Union Creates an EU Law of Liability for Facilitation of Copyright Infringement: Observations on Brein v. Filmspeler [C-527/15] (2017) and Brein v. Ziggo [C-610/15] (2017)', Columbia Law and Economics Working Paper, 2017/572, pp.1-14.

Koo, J. 'Away We Ziggo: The Latest Chapter in the EU Communication to the Public Story', Journal of Intellectual Property Law \& Practice, 13(7), pp. 542-551.

Long, J. (2018) 'Different Solutions for Similar Questions: Hyperlinks and the Right of Communication to the Public in China and the EU', International Review of Intellectual Property and Competition Law, 49, pp. 413-435.

Minero, G. (2014) 'Are Hyperlinks Covered by the Right to Communicate Works to the Public? The Svensson Case: C-466/12 Nils Svensson and Others v Retriever Sverige AB (13 February 2014)', Queen Mary Journal of Intellectual Property, 4(4), pp. 322-327.

Nordemann, J. (2018) 'Recent CJEU Case Law on Communication to the Public and Its Application in Germany: A New EU Concept of Liability', Journal of Intellectual Property Law \& Practice, 13(9), pp. 744-756.

Radosavljev, P. (2017) 'For Whom the Copyright Scale Tips: Has the CJEU Established a Proper Balance of Rights with Its GS Media Case Judgement?', European Journal of Law and Technology, 2017/3, p. 5.

Radziewicz, P. 'Wzruszenie 'domniemania konstytucyjności' aktu normatywnego przez Trybunał Konstytucyjny', Przegląd Sejmowy, 2008/5, pp. 55-88.

Rosati, E. (2017) 'GS Media and Its Implications for the Construction of the Right of Communication to the Public within EE Copyright Architecture', Common Market Law Review, 54(4), pp. 1221-1242.

Visser, D. (2018a) 'Kroniek van de intellectuele eigendom', Nederlands Juristenblad, 2018/93, pp. 1025-1037. 
Visser, D. (2018b) 'Hof van Justitie van de Europese Unie, 7 augustus 2018, C-161/17, ECLI: EU: C: 2018: 634,' AMI: tijdschrift voor auteurs-, media-en informatierecht, 2018/5, pp. 183-190.

Wang, F. (2018) ‘Current developments - Europe', Intellectual Property Forum: Journal of the Intellectual and Industrial Property Society of Australia and New Zealand, 2018/113, pp. 61-65. 